\title{
PENGARUH SEKTOR INDUSTRI PENGOLAHAN TERHADAP PERTUMBUHAN EKONOMI PROVINSI KEPULAUAN BANGKA BELITUNG
}

\author{
Tituk Indrawati \\ BPS Provinsi Kepulauan Bangka Belitung, Pangkalpinang \\ tituk.indrawatid@gmail.com
}

\begin{abstract}
The purpose of this study was to determine the effect of industrial sector on economic growth in Kepulauan Bangka Belitung Province. Data analysis technique used is simple linear regression. The results showed that the Industrial sector had a positive and fignificat effect on Economic Growth in Kepulauan Bangka Belitung Province.
\end{abstract}

Key words : industrial sector, economic growth

\begin{abstract}
Abstrak
Tujuan penelitian ini yaitu untuk mengetahui seberapa besar Pengaruh Antara Sektor Pertanian Dan Industri Pengolahan Terhadap Pertumbuhan Ekonomi Provinsi Kepulauan Bangka Belitung. Teknik analisis data yang digunakan yaitu regresi linear sederhana. Hasil penelitian menunjukan sektor industri pengolahan berpengaruh positif dan signifikan terhadap pertumbuhan ekonomi Provinsi Kepulauan Bangka Belitung.
\end{abstract}

Kata kunci : sektor industri, pertumbuhan ekonomi

\section{Pendahuluan}

Pembangunan merupakan suatu proses untuk menjadikan sesuatu lebih baik. Dalam hal ini suatu usaha untuk menciptakan kesejahteraan rakyat dan mencerminkan proses perbaikan dari suatu masyarakat atau system social secara keseluruhan untuk bergerak maju menuju kondisi yang lebih baik. Umumnya pembangunan negara-negara sedang berkembang dipusatkan pada pembangunan ekonomi yang bisa diukur melalui usaha pertumbuhan ekonomi. Proses pembangunan mengharapkan adanya pertumbuhan ekonomi yang diikuti dengan perubahan struktur ekonomi dan perubahan kelembagaan, namun proses ini tidak mudah karena memerlukan waktu yang cukup panjang.

Pembangunan dilakukan berdasarkan prinsip otonomi daerah dan pengaturan sumber daya nasional yang memberikan kesempatan bagi peningkatan kinerja suatu daerah. Daerah mempunyai kewenangan dan tanggung jawab dalam memenuhi kepentingan masyarakat berdasarkan prinsip-prinsip keterbukaan, partisipasi masyarakat dan pertanggungjawaban kepada masyarakat. Pembangunan dilakukan secara efisien dan efektif dengan perencanaan koordinasi dan keterpaduan antar sektor pembangunan yang disesuaikan dengan kondisi dan potensi yang dimiliki oleh masing-masing daerah. Umumnya tujuan pembangunan dalam kebijakan daerah adalah mengurangi disparitas atau ketimpangan pembangunan antar daerah, mengentaskan kemiskinan, menciptakan lapangan kerja, meningkatkan pendapatan per kapita dan kesejahteraan daerah, menjaga sumber daya alam agar bermanfaat dan dapat mencapai suatu kemandirian daerah.

Salah satu indicator dari keberhasilan pembangunan suatu daerah diukur melalui pertumbuhan ekonomi yang ditunjukkan oleh nilai Produk Domestik Regional Bruto (PDRB). PDRB terdiri dari berbagai sektor perekonomian dan pertumbuhan PDRB tidak lepas dari peran setiap sektor-sektor ekonomi tersebut, besar kecilnya kontribusi pendapatan setiap sektor perekonomian merupakan perencanaan secara sektoral yang dilaksanakan oleh daerah.

Provinsi Kepulauan Bangka Belitung merupakan provinsi termuda di Indonesia Barat. Nilai PDRB Kepulauan Bangka Belitung tahun 2010 sampai 2020 mengalami yang peningkatan yang cukup signifikan dari Rp 35.561.904 juta pada tahun 2010 menjadi Rp 52.702.458 juta pada tahun 2020 (hampir dua 
kali lipat). Dan selama ini Provinsi Kepulauan Bangka Belitung merupakan penghasil timah yang cukup besar serta crude palm oil yang berpotensi, sehingga diharapkan sektor industri pengolahan berkontribusi terhadap perekonomian provinsi. PDRB sektor industri tahun $2010 \mathrm{Rp}$ 9.174.668 juta menjadi Rp 11.256.597 juta pada tahun 2020 .

Sebagai provinsi yang mempunyai sumber daya mineral cukup banyak yaitu pasir timah serta lahan perkebunan kelapa sawit yang cukup luas, maka sektor industri pengolahan berperan penting dalam meningkatkan nilai investasi dan ekspor sehingga menjadi sektor yang penting untuk diperhatikan dalam mengakselerasi pertumbuhan ekonomi. Sektor industri dianggap sebagai the leading sector yang mampu mendorong berkembangnya sektorsektor lain seperti jasa dan pertanian (Arsyad, 2010). Struktur perekonomian suatu wilayah yang relative maju ditandai dengan semakin besarnya peran dari sektor industri pengolahan dalam menopang perekonomian suatu wilayah. Sektor ini akan menggantikan peran sektor pertanian dalam penyerapan tenaga kerja dan sumber wilayah.

\section{Struktur Ekonomi Provinsi Kepulauan Bangka Belitung Tahun 2020}

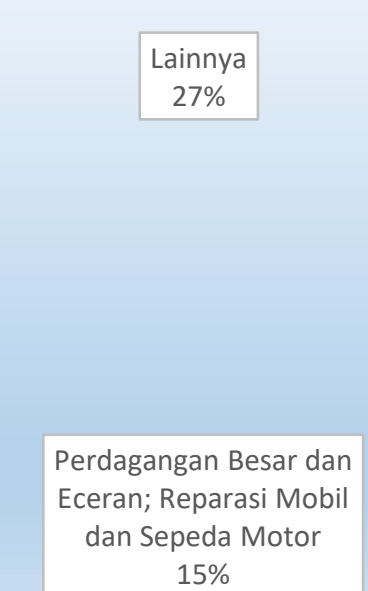



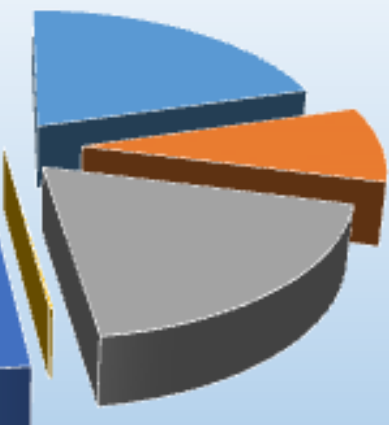

Listrik, Gas dan Air Bersih $0 \%$

Konstruksi
$10 \%$

Pertanian, Kehutanan, dan Perikanan $20 \%$
Industri Pengolahan $19 \%$

Gambar 1. Struktur Ekonomi Provinsi Kepulauan Bangka Belitung Tahun 2020

Kepulauan Bangka Belitung memiliki 3 sektor ekonomi yang berkontribusi besar terhadap PDRB tahun 2020 yaitu 20,47 persen dari Pertanian, Kehutanan dan Perikanan. Sektor kedua dari Industri Pengolahan sebesar 18,76 persen serta 15,33 persen dari sektor Perdagangan Besar dan Eceran, Reparasi Mobil dan Sepeda Motor. Pada tahun 2020 dimana terjadinya pandemic diseluruh wilayah termasuk Provinsi Kepulauan Bangka Belitung yang mengakibatkan sebagian besar sektorsektor ekonomi ini mengalami kontraksi pertumbuhan. Begitupun dengan ketiga sektor tersebut, Industri Pengolahan dan Perdagangan Besar dan Eceran, Reparasi Mobil dan Sepeda Motor masing-masing tumbuh sebesar $-5,64$ dan $-4,62$ persen. Namun hanya sektor Pertanian, Kehutanan dan Perikanan menjadi kontributor utama sektor yang dapat tumbuh positif hingga 8,31 persen.
Berdasarkan beberapa hal diatas, maka Tujuan dari penelitian ini adalah untuk mengetahui apakah Sektor Industri Pengolahan dapat mempengaruhi pertumbuhan ekonomi Provinsi Kepulauan Bangka Belitung.

\section{Metode Penelitian}

Penelitian dilakukan di Provinsi Kepulauan Bangka Belitung dengan menggunakan data sekunder yaitu PDRB Provinsi Kepulauan Bangka Belitung periode 2010-2020. Data bersumber pada Badan Pusat Statistik Provinsi Kepulauan Bangka Belitung.

Dalam penelitian yang bertujuan untuk mengetahui pengaruh sektor industri terhadap pertumbuhan ekonomi di Provinsi Kepulauan Bangka Belitung digunakan merode uji regresi linear sederhana. Model yang digunakan dalam penelitian ini adalah

$$
Y=a+\beta X+e
$$


Keterangan $\mathrm{Y}$ : Pertumbuhan ekonomi

$X$ : Sektor industri pengolahan

a : Konstanta

$\beta$ : Nilai Koefisien $X$

e : Error Term

\section{Hasil Penelitian dan Pembahasan}

Hasil Penelitian

Sektor industri pengolahan Provinsi Kepulauan Bangka Belitung tahun 2010 - 2020 mengalami peningkatan yang cukup signifikan, hal ini ditunjukan dengan angka PDRB dari sektor industri pengolahan atas dasar harga konstan yang tercipta terus meningkat sebesar Rp. 9.174.668 juta pada tahun 2010 menjadi Rp. 11.256.597 juta pada tahun 2020. Meskipun peningkatannya menunjukkan tren yang positif namun pada tahun 2020, sektor industri pengolahan mengalami penurunan pada tahun 2020 yang disebabkan oleh beberapa hal namun utamanya adalah adanya pandemic COVID19 di Kepulauan Bangka Belitung.

Hal ini sejalan dengan pertumbuhan ekonomi yang bisa di tunjukkan pada besaran PDRB atas dasar harga konstan Provinsi Kepulauan Bangka Belitung tahun 2010 - 2020 yang meningkat dari Rp. 35.561.904 juta pada tahun 2010 menjadi Rp. 52.702.458 juta pada tahun 2020. Begitupun dengan pertumbuhan ekonomi pada tahun 2020 yang mengalami konstraksi sebesar $-2,30$ persen apabila dibandingkan dengan tahun sebelumnya.

Tabel 1

Nilai PDRB Total dan Sektor Industri Provinsi Kepulauan Bangka Belitung Tahun 2010 - 2020

\begin{tabular}{rrr}
\hline Tahun & $\begin{array}{c}\text { PDRB Sektor } \\
\text { Industri } \\
\text { Pengolahan }\end{array}$ & PDRB Total \\
\hline 2010 & $9,174,668$ & $35,561,904$ \\
2011 & $9,515,757$ & $38,013,990$ \\
2012 & $9,804,878$ & $40,104,906$ \\
2013 & $10,143,284$ & $42,190,857$ \\
2014 & $10,270,405$ & $44,159,440$ \\
2015 & $10,400,640$ & $45,962,304$ \\
2016 & $10,680,473$ & $47,848,372$ \\
2017 & $11,337,680$ & $49,985,154$ \\
2018 & $11,787,737$ & $52,208,035$ \\
2019 & $11,928,855$ & $53,940,422$ \\
2020 & $11,256,597$ & $52,702,458$ \\
\hline
\end{tabular}

A. Pembahasan

Berdasarkan hasil olah data diperoleh persamaan untuk regresi linear sederhana sebagai berikut

$$
Y=25114532,69+6,698 X+e
$$

Dari persamaan diatas diperoleh nilai konstanta sebesar 25114532,69. Artinya bahwa jika Produk Domestik Regional Bruto (PDRB) sektor industri pengolahan Kepulauan Bangka Belitung bernilai 0 (nol), maka pertumbuhan ekonomi Provinsi Kepulauan Bangka Belitung akan dipengaruhi sebesar 25114532,69. Begitupun dengan nilai koefisien regresi variable sektor industri pengolahan sebesar 6,698 menunjukkan bahwa jika nilai sektor industri pengolahan naik sebesar 1 (satu) maka nilai pertumbuhan ekonomi Provinsi Kepulauan Bangka Belitung akan mengalami kenaikan sebesar 6,698. Hal ini berarti bahwa sektor industri pengolahan memiliki hubungan positif dengan pertumbuhan ekonomi Provinsi Kepulauan Bangka Belitung. Dan apabila sektor industri pengolahan meningkat maka pertumbuhan ekonomi Provinsi Kepulauan Bangka Belitung dalam hal ini adalah PDRB atas dasar harga konstan akan meningkat juga.

Apabila dilihat nilai Multiple $R$ ( $r$ ) yang mendekati satu atau sebesar 0,979 yang berarti bahwa antara variable terikat dalam hal ini pertumbuhan ekonomi dengan variable bebas yaitu sektor industri pengolahan menunjukkan hubungan yang kuat. Jika dilihat dari hasil uji determinasi untuk Adjusted R Square sebesar 0,9550 menunjukkan bahwa pengaruh sektor industri pengolahan terhadap pertumbuhan ekonomi sebesar 95,50\% sedangkan sisanya $4,50 \%$ dipengaruhi oleh variable lain yang tidak termasuk dalam variable penelitian. Didukung dengan nilai signifikansi sebesar 0,000 lebih kecil dari $0,05(0,000<0,05)$ yang menunjukkan bahwa sektor industri pengolahan berpengaruh sangat signifikan terhadap pertumbuhan ekonomi Provinsi Kepulauan Bangka Belitung.

Dengan hasil penelitian diatas maka tantangan yang dihadapi Provinsi Kepulauan Bangka Belitung dalam pelaksanaan strategi pembangunannya adalah bagaimana lebih meningkatkan produktivitas dan efisiensi di semua sub sektor industri pengolahan dalam menghasilkan berbagai komoditas agar dapat memberikan nilai tambah yang sebesarbesarnya kepada masyarakat, khususnya dengan mengoptimalkan segala potensi yang 
dimiliki daerahnya. Peningkatan produktivitas dan efisiensi ini akan tepat sasaran apabila pemerintah Kepulauan Bangka Belitung bisa merinci potensi tersebut hingga ke subsektorsebsektor industri pengolahan.

Pemerintah Provinsi Kepulauan Bangka Belitung perlu mengidentifikasi dari subsektorsubsektor industri pengolahan yang beragam akan muncul komoditas-komoditas unggulan. Sehingga akan lebih tepat sasaran untuk meningkatkan produktivitas serta mengembangkan komoditas unggulan yang dimiliki daerah seperti hasil industri pengolahan yang diantaranya adalah logam timah, crude palm oil, pembekuan hasil laut/fillet hasil laut, lada bubuk baik hitam maupun putin, batik khas cual dan lain-lain.

Hasil penelitian ini sejalan dengan penelitian yang dilakukan Ahmad Shodiqin (2018) yang menunjukkan bahwa sektor industri pengolahan berpengaruh terhadap pertumbuhan ekonomi Kota Bandar Lampung. Begitupun dengan Kepulauan Bangka Belitung yaitu dengan mengoptimalkan sektor industri pengolahan maka akan meningkatkan PDRB Provinsi Kepulauan Bangka Belitung. Sesuai dengan teori Hirschman, sektor industri pengolahan dianggap sebagai sektor pemimpin (the leading sector), pertumbuhan yang cepat dari satu atau beberapa industri pengolahan akan mendorong perluasan industri-industri lainnya yang terkait. Ataupun kemungkinan dengan banyaknya sumber daya alam yang melimpah bisa mendorong pertumbuhan industri pengolahan (sebagai bahan mentah).

Dengan demikian dapat dikatakan bahwa sektor industri pengolahan memegang suatu peranan yang cukup penting dalam pembangunan ekonomi suatu daerah karena melalui pembangunan industri maka akan memacu dan memajukan pembangunan sektorsektor lainnya. Dan diharapkan dapat menciptakan peluang kerja untuk dapat menyerap tenaga kerja lebih banyak dan pada gilirannya nanti akan meningkatkan pendapatan masyarakat secara keseluruhan, karena pertumbuhan ekonomi ditandai dengan meningkatnya pendapatan per kapita masyarakatnya.

\section{Kesimpulan}

Berdasarkan hasil penelitian dan pembahasan hasil penelitian dapat disimpulkan bahwa sektor industri pengolahan berpengaruh positif dan signifikan terhadap pertumbuhan ekonomi Provinsi Kepulauan Bangka Belitung.

Adapun saran dari penelitian ini yaitu :

1. Pemerintah Provinsi Kepulauan Bangka Belitung dapat lebih fokus meningkatkan produktivitas sektor-sektor industri pengolahan yang merupakan komoditas unggulan maupun mengembangkan sektor-sektor industri pengolahan yang mempunyai bahan mentah melimpah di dalam provinsi. Karena dengan mengembangkan sektor industri pengolahan dapat meningkatkan pertumbuhan ekonomi secara nyata di Provinsi Kepulauan Bangka Belitung.

2. Diperlukan adanya penelitian lebih lanjut untuk mengetahui sektor industri pengolahan yang mana yang berpotensi untuk dikembangkan di Provinsi Kepulauan Bangka Belitung dengan mengetahui jumlah tenaga kerja, upah tenaga kerja, asal bahan baku serta nilai produksi yang dihasilkan dari sektorsektor industri pengolahan yang ada. Sehingga pemerintah Provinsi Kepulauan Bangka Belitung dapat memberikan perhatian yang lebih kepada sektor industri pengolahan tersebut.

\section{Daftar Pustaka}

Admin Sevima. 2019. Cara Mudah Membuat Jurnal Ilmiah Yang Benar dan Baik. www.sevima.com (25 Februari 2021)

Ahmad Shodiqin. 2018. Pengaruh Industri Pengolahan Terhadap Pertumbuhan Ekonomi Kota Bandar Lampung Dalam Perpektif Ekonomi Islam Periode 20102016. Skripsi Fakultas Ekonomi Dan Bisnis Islam Universitas Islam Negeri Raden Intan Lampung.

Anwar Hidayat. 2012. Tutorial Analisis Regresi dengan Excel. www.statistikian.com (2 Maret 2021)

Arsyad L. 2016. Ekonomi Pembangunan. Edisi Kelima. Yogyakarta

BPS Provinsi Kepulauan Bangka Belitung. 2020. Kepulauan Bangka Belitung Dalam 
Angka 2020. Pangkalpinang. BPS Provinsi Kepulauan Bangka Belitung

Juanda B. 2009. Ekonometrika Permodelan dan Pendugaan. Bogor: IPB Press

Rizky Pratama. 2019. Cara Menulis Daftar Pustaka dari Buku, Jurnal dan Internet. www.bocahkampus.com (25 Februari 2021)

Todaro, MP dan Stephen, CS. 2006. Pembangunan Ekonomi. Jakarta. Erlangga 